\title{
Design insights for Socially-led interventions
}

Design has become an accessible tool for organisations to create impactful outputs. These topics have diverged from mere retail to include; economic prospects, technological paradigms, social empowerment, sustainable resources, citizen-led opportunities and challenges that cross demographics, societies and cultures. Accessible technologies and the reduction of barriers to pilot funding have (in part) enabled the advancement of these socially led responses through design. 'Enablers' take many forms including; digital manufacturing, accessible hardware, design platforms, smart technologies all, challenging what 'designed products' are... as the 'product' is a social impact or intervention. The work mines embedded knowledge from successful award winning organisations, which have not publically shared their unique insights.

The work analyses an interview series of 60 plus CEO's, founders and co-founders of socially-led organisations with both design and non-design origins. The work identifies socially-led design 'architectures' highlighting; issues, lessons and transferable insights. The study includes global organisations occupying territories of: not-for-profits, commercial practices, grass roots organisations, science practitioners, community led ventures and intellectual property enterprises, selected from leading awards. The article identifies insights leading towards 'Socially-led product architecture', and repeatable lessons, for non-design and design audiences.

\section{Keywords:}

Socially-led Design, Design for Agency, Product Architecture, Not-for-profit, financially Sustainable, Design Approaches

\section{Introduction}

The article highlights socially-led design instances through 'enablers' from first hand research with CEO's and Co-founders. The interview series gathered insights that can be applied to 'socially-led product architecture' for non-design and design audiences. The objective of the research is to find attributes that scaffold these successful organisations for alternate use.

\section{What is Socially-led Design?}

Design is a valuable tool in "provid[ing] a deeper understanding of people's needs" (Design Council, 2017) The designer "is a 'connectivist' with an inherent capacity to establish and foster links between disciplines and cultures" (Cahalan, 2007). Social Design "points to projects or products that are principally concerned with society" (Van der Zwaag, 2014) or "a socially responsible design practice may take on any number of forms of intervention, education or advocacy - even spinning off nonprofits or non-governmental associations" (Emmerson, 2018). In Design with society: why socially responsive design is good enough Thorpe \& Gamman define an "assetbased approach is a key facet of socially responsive design and innovation. It assumes that as a designer you do what you can, working with other social actors to leverage the community's assets to effect positive change" (Thorpe, Gamman 2011). The infamous Papanek foundation (papanek.org), the legacy of 'Design for the real World' believes that design should embrace "the perspective of social responsibility" (Papanek, Fuller 1972). Thorpe \& Gamman propose "that socially responsive design is a different kind of design from Papanek, offer[ing] a new account of design, one that abrogates notions of design's (and designers') responsibility in favour of 
responsivity" (Thorpe, Gamman 2011). Social Design "comprises all design disciplines that support a sustainable lifestyle and that offer alternatives for the current social and economic systems" (Van der Zwaag, 2014).

Design consultancy IDEO, underpins this approach in the Little Book of Design Research Ethics sharing principles of "Respect, Responsibility and Honesty" directing toward "protect[ing] people's current and future interests" (IDEO, 2015). IDEO designer Tim Brown believes "systematic problems need systematic solutions" (Brown, T \& Wyatt J 2010) embracing new product architectures of 'product, service and system'. Libertarian and political philosopher Karl Hess defines Community Technology as resources "enabl[ing] scientists, engineers, technicians and craftpeople to re-think the roles of their skills and talents, to become part of everyday life" (Wade, 1975). Cooper summaries the "need to shift from the focus on single issues toward taking a more holistic approach" to achieve socially responsible design (Cooper, 2005).

A Cooper-Hewitt, Design and Social Impact white paper highlights an objectionable view to isolate socially-led design practice but "would like more designers to engage [in] social responsibility as part of the ethos of their work" (Irwin, 2015). The white paper highlights the challenge territories to include: "cultural bias, ethics and standards, sustainability, implementation and impact", ensuring it is not a silver bullet, but contextually, culturally and geographically based (Irwin, 2015). Social Design "can overcome these limits by developing richer discourses of the social by building on its own legacy, using the expertise from both worlds and joining forces between social scientists and designers, next to other stakeholders involved in social design projects" (Chen, Cheng et al. 2016). An example of this is The Peoples Supermarket "a co-operative; [where] members annually pay $£ 25$, and volunteer four hours a month (Williams, 2018). For membership they get a $20 \%$ discount, NHS workers get $10 \%$. The shop in Bloomsbury, London: with no economies of scale, and no classic supermarket deal slicing" i.e. it is a format for better local provision (Williams, 2018).

\section{Enabler}

The Cambridge dictionary defines 'enablers' as "something or someone that makes it possible for a particular thing to happen" (Dictionary, 2006). In this context they are technologies or mechanisms that create a community facing set of opportunities. Deibert (et al) comment in DIY Citizenship that there can be "no doubt that the Internet and its related tools, like social networking and mobile computing, have placed powerful capabilities in the hands of individuals who collectively have used them in innovative ways" (Ratto, Boler 2014). These 'related tools' are enablers, that Social Design forefather Manzini highlights as the "diffusion of the Internet, mobile phones and social media, converging with social innovation, has enabled the creation of a new generation of services, providing a relationship between citizen and state" (Manzini, Coad 2015). Manzini continues to clarify that "people may not be solving their own problems, they may also be setting the basis of a new civilisation" (Manzini, Coad 2015). The 2018 annual meeting report of the World Economic Forum, presents how 'enablers' and "emerging technologies, will give [people], irrespective of where they are born or raised, the unique skills to take advantage of a new digital economy" (Bridges, M. et al, 2018). These enablers at societies disposal 
include; community technologies, social impact, business, accessible design, modern needs and cultural bias.

\section{Product Architecture}

Ulrich defines product architecture as "the scheme by which the function of a product is allocated to physical components" (Eppinger, Ulrich 1995). Volkswagen claims to "save $\$ 1.7$ billion annually on development and production costs through effective product architecture. Volkswagen is able to take advantage of platform and component commonality by sharing between its four major brands, namely VW, Audi, Skoda, and Seat" (Dahmus, Gonzalez-Zugasti et al. 2001). Product architecture "can have a large impact on the performance, cost, and profitability of a product. In particular, well-researched architecture design can be leveraged to maximum advantage when applied to a set of multiple products that share common elements" (Yu, Gonzalez-Zugasti et al. 1999).

Product architecture contains "the information on how many components the product consist of, how these components work together, how they are built and assembled, how they are used, and how they are disassembled. As such, the product architecture serves the purpose of defining, the basic physical building blocks of the product in terms of what they do and what their interfaces are to the rest of the device" (Eppinger, Ulrich 1995). Product architecture can be "nominally defined as a comprehensive description of a bundle of product characteristics, including number and type of components, and number and type of interfaces between those components, and, as such, represents the fundamental structure of the product" (Fixson, 2005). Models of product architecture include: modular (Dahmus et al. 2001), adaptable design (Yu et al. 1999), platform (Stone, Wood et al. 1999), portfolio architecture (Yu et al. 1999), fixed portfolio (Jacobs, Swink 2011), customisable (Sosa, Eppinger et al. 2004), consumable platforms (Yu et al. 1999), adjustable (Zamirowski, Otto 1999), for purchase platforms (Yu et al. 1999). The culmination of enablers, socially-led design and diverse product architectures provide agency to numerous audiences and thus "the capacity to act" (Denizen, 2018).

\section{Method}

The organisations included were selected from leading social design awards: Nominet Trust Impact (www.nominettrust.org.uk), Tech for Good (www.tech4goodawards.com), D\&AD Impact (www.dandadimpact.com), Core77 Design for Social Impact (designawards.core77.com/2017/Design-for-Social-Impact), Good Design (www.good-designawards.com), IF World Design Guide (ifworlddesignguide.com/if-social-impact-prize), Social Impact Festival (socialimpactfestival.org), The Do Lectures (www.thedolectures.com), Autodesk foundation (www.autodesk.org/), TED Ideas Worth Spreading (www.ikeafoundation.org), Ikea Foundation (www.ikeafoundation.org), Royal Academy's MacRobert Award (www.raeng.org.uk), Civic Tech 4 Democracy (www.civictech4democracy.eu) and the Bill \& Melinda Gates Foundation (www.gatesfoundation.org) over the last 3 years.

The selected organisations had addressed at least 3 challenges of the future, highlighted by the World Economic Forum, Global Risks Report 2018 and due to conditions of (Fig 1.) (World Economic Forum, 2018). The insights from the 60 socially led organisations used design interventions based in global issues that can be 
translated into local approaches and organised into the following fields; Civic Empowerment, Healthcare, Environment \& Sustainability, Accessible Design, Economic Empowerment, Community Engagement and Access to Knowledge, used by the Nominet Trust in their recent report Transforming Lives with Tech A Global Conversation (The Nominet Trust, 2018).

The organisations are also spread across the market (Fig 2.); bottom up, top down, technology push and market pull. Bottom up "identifies local problems, and chalks out local innovative strategies and methods to mitigate these. This approach taps the indigenous knowledge bases and local expertise" (Panda, 2007) . Top down "refers to situation[s] in which decisions are made by a few people in authority, rather than by the people who are affected by the decisions" (Dictionary, 2006). Technology Push is defined "when you have the technology and have to design a product that would use the technology" (Designkmg, 2018). Market Pull delineates "when there is a need in the market, so you design a product to meet that need" (Designkmg, 2018).

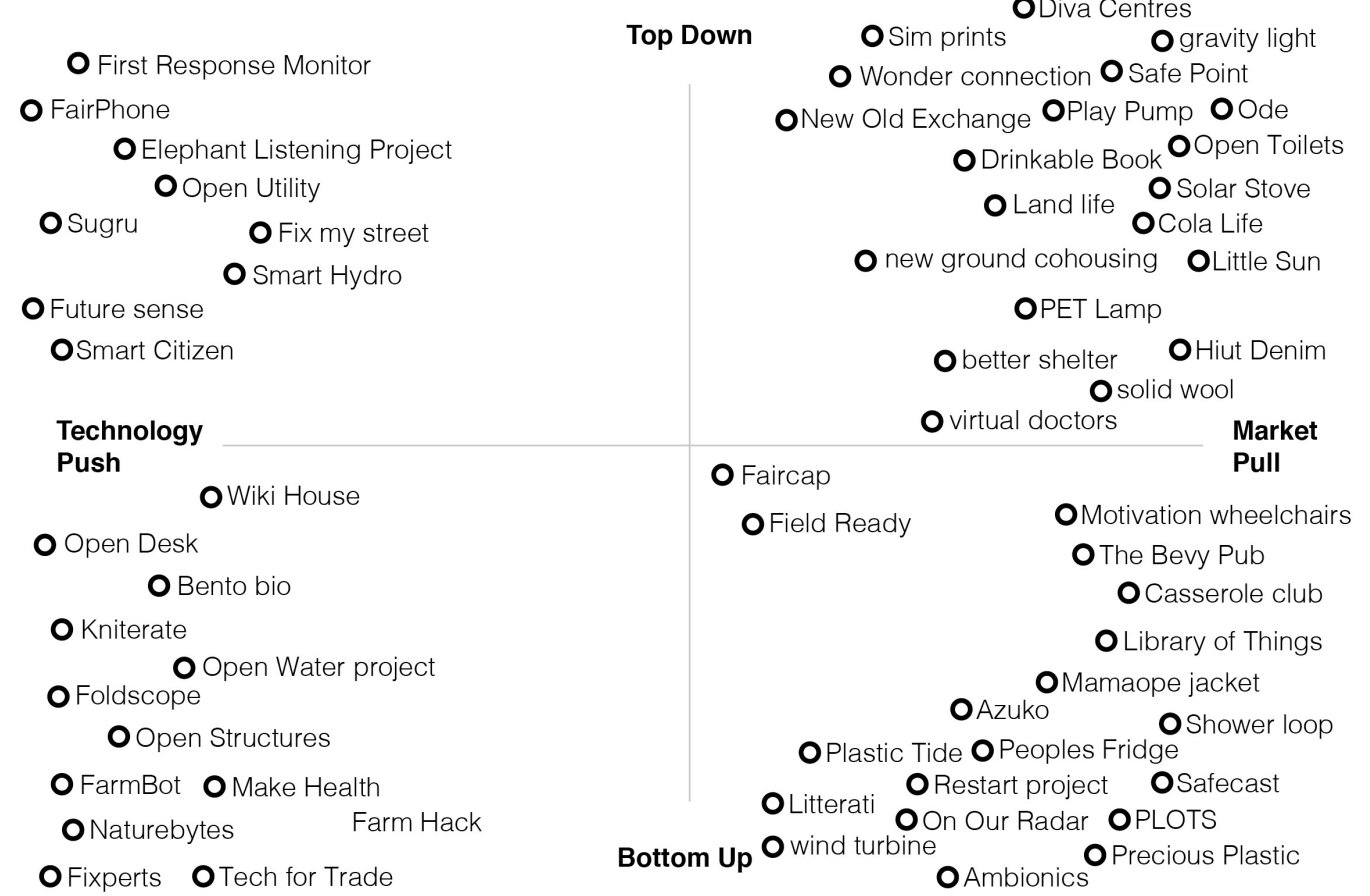

\section{Figure 1: Map of Interviewed Organisations.}

Each interview used a "general interview guide approach", participants highlighted their backgrounds, their perceived value, their definition of Social Design and insights/lessons for wider audiences (Gall, Borg et al. 1996). In this analysis, data from the interview series have been analysed to highlight the most relevant themes across the different organisations. Interview process used (Ritchie, J. and J. Lewis. 2013) to ensure that "the emphasis on depth, nuance and the interviewee's own language as a way of understanding meaning implies that interview data needs to be captured in its natural form" (Ritchie, Lewis et al. 2013).

The participants were interviewed either by phone or Skype based on their location reducing barriers to just accessible contacts. Each of the interviewess were asked;

1. What is the back-story to the projects conception? 
2. What is your core mission statement and who is your most important audience?

3. What is the strongest impact, case study, story or example that has come out of your venture?

4. How do you think social design / social technology can become more financially sustainable, reaching beyond the charitable / NGO model?

5. What are the future issues, challenges and opportunities that we as a design community must address for generations to come?

The work was analysed using Nvivo, to charecterise familiar traits in the interviews and cluster results. The organisations were grouped into the following categories; Civic Empowerment, Healthcare, Environment \& Sustainability, Accessible Design, Economic Empowerment, Community Engagement and Access to Knowledge, groupings extracted from (Tech for Good, www.techforgood.global).

\begin{tabular}{|c|c|c|c|c|c|c|}
\hline $\begin{array}{l}\text { Civic } \\
\text { Empowerment }\end{array}$ & Healthcare & $\begin{array}{l}\text { Environment \& } \\
\text { Sustainability }\end{array}$ & $\begin{array}{l}\text { Accessible } \\
\text { Design }\end{array}$ & $\begin{array}{l}\text { Economic } \\
\text { Empowerment }\end{array}$ & $\begin{array}{l}\text { Community } \\
\text { Engagement }\end{array}$ & $\begin{array}{l}\text { Access to } \\
\text { Knowledge }\end{array}$ \\
\hline $\begin{array}{l}\text { Better Shelter } \\
\text { (Modular) }\end{array}$ & $\begin{array}{l}\text { Cola Life } \\
\text { (Empowering } \\
\text { Tool) }\end{array}$ & $\begin{array}{l}\text { Farm bot } \\
\text { (Open) }\end{array}$ & $\begin{array}{l}\text { Sugru } \\
\text { (Customizable) }\end{array}$ & $\begin{array}{l}\text { PET Lamp } \\
\text { (Adaptable } \\
\text { Design) }\end{array}$ & $\begin{array}{l}\text { Casserole } \\
\text { Club } \\
\text { (Empowering } \\
\text { tools) }\end{array}$ & $\begin{array}{l}\text { Open Utility } \\
\text { (For Purchase } \\
\text { Platform) }\end{array}$ \\
\hline $\begin{array}{l}\text { Fix my Street } \\
\text { (Platform) }\end{array}$ & $\begin{array}{l}\text { Safe Point } \\
\text { (Better for } \\
\text { All) }\end{array}$ & $\begin{array}{l}\text { Fairphone } \\
\text { (Consumable } \\
\text { Platform) }\end{array}$ & $\begin{array}{l}\text { Wiki House } \\
\text { (Open Platform) }\end{array}$ & $\begin{array}{l}\text { Motivation } \\
\text { Wheelchairs } \\
\text { (Adaptable } \\
\text { Design) } \\
\end{array}$ & $\begin{array}{l}\text { Fixperts } \\
\text { (Platform) }\end{array}$ & $\begin{array}{l}\text { Wonder } \\
\text { connection } \\
\text { (Empowering } \\
\text { tools) }\end{array}$ \\
\hline $\begin{array}{l}\text { Future Sense } \\
\text { Project (Modular) }\end{array}$ & $\begin{array}{l}\text { Response } \\
\text { Monitor } \\
\text { (Empowering } \\
\text { tools) } \\
\end{array}$ & $\begin{array}{l}\text { Shower Loop } \\
\text { (Open) }\end{array}$ & $\begin{array}{l}\text { Nature Bytes } \\
\text { (Open Platform) }\end{array}$ & $\begin{array}{l}\text { PlayPump } \\
\text { (Fixed } \\
\text { Portfolio) }\end{array}$ & $\begin{array}{l}\text { New Old } \\
\text { Exchange } \\
\text { (Experience) }\end{array}$ & $\begin{array}{l}\text { Bento Lab } \\
\text { (Empowering } \\
\text { tools) }\end{array}$ \\
\hline Solar Stove (Open) & $\begin{array}{l}\text { Mamaope } \\
\text { Jacket (Fixed } \\
\text { Portfolio) }\end{array}$ & $\begin{array}{l}\text { Gravity Light } \\
\text { (Adaptable } \\
\text { Design) }\end{array}$ & $\begin{array}{l}\text { Open Structures } \\
\text { (Open Platform) }\end{array}$ & $\begin{array}{l}\text { Hiut Denim } \\
\text { (For Purchase } \\
\text { platform) }\end{array}$ & $\begin{array}{l}\text { The Bevy, } \\
\text { Social Pub } \\
\text { (Social } \\
\text { Innovation) }\end{array}$ & $\begin{array}{l}\text { Restart project } \\
\text { (Social } \\
\text { Platform) }\end{array}$ \\
\hline $\begin{array}{l}\text { Open Toilets } \\
\text { (Platform) }\end{array}$ & $\begin{array}{l}\text { Faircap } \\
\text { (Open) }\end{array}$ & $\begin{array}{l}\text { Smart Hydro } \\
\text { power (Fixed } \\
\text { Portfolio) }\end{array}$ & $\begin{array}{l}\text { Kniterate (Open } \\
\text { Platform) }\end{array}$ & $\begin{array}{l}\text { Azuko } \\
\text { (Empowering } \\
\text { tools) }\end{array}$ & $\begin{array}{l}\text { New ground } \\
\text { cohousing } \\
\text { (Better for } \\
\text { All) } \\
\end{array}$ & $\begin{array}{l}\text { Elephant } \\
\text { Listening } \\
\text { Project (Fixed } \\
\text { Portfolio) } \\
\end{array}$ \\
\hline Litterati (Platform) & $\begin{array}{l}\text { Ode } \\
\text { (Empowering } \\
\text { tools) } \\
\end{array}$ & $\begin{array}{l}\text { KTK - belt } \\
\text { (Platform) }\end{array}$ & $\begin{array}{l}\text { Ambionics } \\
\text { (Open) }\end{array}$ & $\begin{array}{l}\text { Open Desk } \\
\text { (Open Platform) }\end{array}$ & $\begin{array}{l}\text { Solidwool } \\
\text { (Fixed } \\
\text { Portfolio) } \\
\end{array}$ & $\begin{array}{l}\text { Foldscope } \\
\text { (Fixed } \\
\text { Portfolio) } \\
\end{array}$ \\
\hline $\begin{array}{l}\text { Public lab (PLOTS) } \\
\text { (Community } \\
\text { Empowerment) }\end{array}$ & $\begin{array}{l}\text { Diva Centres } \\
\text { (Social } \\
\text { Innovation) }\end{array}$ & $\begin{array}{l}\text { Land life (Fixed } \\
\text { Portfolio) }\end{array}$ & $\begin{array}{l}\text { Field Ready } \\
\text { (Open) }\end{array}$ & $\begin{array}{l}\text { Sim prints (for } \\
\text { Human Rights) }\end{array}$ & $\begin{array}{l}\text { Library of } \\
\text { Things } \\
\text { (Social } \\
\text { Innovation) } \\
\end{array}$ & $\begin{array}{l}\text { Smart Citizen } \\
\text { (Platform) }\end{array}$ \\
\hline $\begin{array}{l}\text { Peoples Fridge } \\
\text { (Social Innovation) }\end{array}$ & $\begin{array}{l}\text { Drinkable } \\
\text { Book (Fixed } \\
\text { Portfolio) } \\
\end{array}$ & $\begin{array}{l}\text { Farm Hack } \\
\text { (Platform) }\end{array}$ & $\begin{array}{l}\text { Safecast } \\
\text { (Platform) }\end{array}$ & & & \\
\hline \multirow[t]{3}{*}{$\begin{array}{l}\text { On Our Radar } \\
\text { (Platform) }\end{array}$} & $\begin{array}{l}\text { Make Health } \\
\text { (Open } \\
\text { Platform) } \\
\end{array}$ & $\begin{array}{l}\text { Solar lamp } \\
\text { (Adaptable } \\
\text { Design) } \\
\end{array}$ & $\begin{array}{l}\text { Precious Plastic } \\
\text { (Platform) }\end{array}$ & & & \\
\hline & $\begin{array}{l}\text { Virtual } \\
\text { doctors (Fixed } \\
\text { Portfolio) }\end{array}$ & $\begin{array}{l}\text { Wave powered } \\
\text { energy (Fixed } \\
\text { Platform) } \\
\end{array}$ & $\begin{array}{l}\text { Open Water } \\
\text { project (Open } \\
\text { Platform) }\end{array}$ & & & \\
\hline & & $\begin{array}{l}\text { Plastic Tide } \\
\text { (Platform) }\end{array}$ & & & & \\
\hline
\end{tabular}

Table 2: Table of interviewed organisations.

\section{Results}

The selected organisations led to the following titles post analysis: Design society (by the community), Designing for (local variables and deployment), Design for agency 
including lead and lay audiences (civic empowerment), Designing (for human rights), Design licensing (better for user, producer and business). All of the organisations were interviewed and 6 key parties have been selected as they identify as pillars of their fields and the most disruptive 'product architectures'. The selected organisations led to the following titles post analysis: Design society (by the community),

Designing for (local variables and deployment), Design for agency including lead and lay audiences (civic empowerment), Designing (for human rights), Design licensing (better for user, producer and business).

\section{Case 1) SimPrints}

The World Bank declares in excess of 1.5 billion people ( 1 in 5) internationally do not officially exist, lacking formal identification (The World Bank, 2018). SimPrints are a non-profit tech company "transforming identification, through biometric technology that is $228 \%$ more accurate with worn fingerprints typical of last mile beneficiaries" (www.simprints.com). Their goal disrupts inaccuracies currently used to track and deliver social impact. Their open source software and biometric hardware builds on mobile tools used by NGOs and governments, internationally fighting poverty and designing for the human rights to be identified. Alexandra Grigore, SimPrints cofounder and Nathaniel Giraitis, strategy director Smart Design shared their experiences.

\section{Figure 2: The SimPrints Challenge.}

\section{Figure 3: The SimPrints Device.}

SimPrints mission "is building, deploying and sustaining the world's most accessible identification tools ending poverty and preventable suffering. We are building systems enabling people without formal ID to access services in healthcare, education, finance etc. Imagine life without ID making it near impossible, to access services, especially in developing countries, i.e. Sub-Saharan Africa or South Asia". SimPrints recognised medics "were unable to identify people: you enrol patients, provide treatment and five months later, that patient returns. It is impossible to find records because patients don't know their date of birth or have unique identifiers". Giraitis stated "my focus was defining design research methodologies to uncover insights ensuring our designs were appropriately user centred. There are feedback loops in the private world i.e. selling, something sells poorly, it's going poorly. In the non-profit world, it's a well-deserving idea, or the ideal tech, but they don't create user-centred impact".

During the SimPrints collaboration "Smart Design wasn't providing physical designs, but teaching mechanisms to deploy design and research methods. We're working with an NGO called 'BRAC', the largest development NGO in the world, serving 90 million people in Bangladesh. One project within maternal healthcare; equipped community health workers with identification tools ensuring pregnant mothers get antenatal care visits. Community health workers trekked house to house within their region to ensure treatments to pregnant mothers". The "first time we asked people to use the scanners, they placed their fingers incorrectly. The boxed technology wasn't enough requiring an additional layer of user experience enabling impact in daily life". SimPrints "thought it's easy to keep your finger straight, but for people with arthritis or those excessively working in fields, they can't straighten their fingers. In Bangladesh we worked with community health workers designing solutions that we're 
now using in other contexts. We interviewed and shadowed community health workers contextually understanding their lives and will be scaling that project to reach 4.8 million pregnant mothers".

Smart Design highlighted the "importance of empowering teams with methodologies, to understand cultural meanings of symbols, thumbs up, thumbs down, green, red? As we imparted user-centred knowledge to SimPrints, they worked with the NGOs in Bangladesh passing knowledge by proxy creating community ambassadors. When the SimPrints team flew back to Cambridge, connections remained in Bangladesh to remotely get feedback to improve designs, for and with end recipients. Having a local ambassadors for continual feedback and improvement of the solution is something they're building into future contracts with NGOs internationally".

SimPrints categorically state, "If you want to design any technology with a social purpose, get to know your users. A lot of groups want to develop a technology for developing countries without going there. You need to go, to build champions because you won't get real-time feedback". You "have to go there, and you won't be able to fly there more than once every few months. You can't spend more than, a few weeks, at most, with your users. It's very critical to train user champions. Making sure that you have the right training in place and the right knowledge transfer protocols or methods to train people in the field to pass on appropriate feedback. Before the feedback starts, going there and making sure that you include the users in a lot of the co-creation exercises. Everything is “contextual, you won't speak the same language as your users. It's critical to train translators, and not just hire them to translate. We identified that translators weren't capturing peoples subtle communications, leading to translator training prior to user feedback in the field".

Finally adapting "design methodologies for social development contexts is critical. We tried; intuition tests, shadowing, card sorting and co-creation so users make personal designs. Being flexible and admitting not all methods work in contexts. You get more information by having people choosing visually with prototypes rather than asking, 'what do you think about this?' We spent days in the field without useful information because translators asked excessive leading questions and not encouraging users to be honest with feedback". There "needs to be continued engagement. You need to build tools and mechanisms for feedback and anticipate a tail to that impact story, it's not just for the end beneficiaries, but it's by the end beneficiaries".

\section{Case 2) K1 Syringe}

Marc Koska OBE is an advocate and global health campaigner, using design interventions to yield large impacts. During Marc's research with the World Health Organisation, he learnt that unsafe injections cause 230,000 HIV infections, 1,000,000 Hepatitis C infections annually and 21,000,000 Hepatitis B infections result in 1,300,000 deaths a year (Mandelbaum-Schmid, 2015). The unique innovation transforms existing manufacturing lines to create a modified hypodermic syringe that can only be used once (Clark, 2015). This requires the contextualisation that syringes, in the developing world especially, are re-used multiple times, and are a transmission boost for virulent viruses between patients in hospitals (Clark, 2015). This is not a new thing; it was first observed back in 1931, with malaria spreading throughout a couple of regiments in the British Army (Brabin, 2014). 
Their commercial strategy: target developing world manufacturers, ensuring availability and global affordability. Their technology has established non-reusable syringes as an attainable standard for all global health. The design was openly licensed and engineered to fit all syringe manufacturing machines, leading to global availability. It has been the driving force behind the $70 \%$ cost reduction of safe syringes witnessed in Unicef's pricing in the last decade (www.safepointtrust.org). The syringe is approved by $\mathrm{WHO}$ and is suitable for curative and immunisation markets; in 2008, they passed their billionth manufactured output (Anonymous 2018d, Department of Protection of the Human Environment, Department of Vaccines and Biologicals 2002). Marc established SafePoint, a foundation offering solutions to this problem, raising awareness about this silent epidemic. The foundation offers healthcare workers better circumstances to deliver cleaner injections, educating people to ensure medical injection safety.

The unintended consequence of someone giving an unsafe injection was that, three/six months later, they contract another virus. "People go into hospital with, for example, a bad knee and they get a couple of injections whilst there. They then come out with Hepatitis B (for example) and this becomes a death sentence to their families". In interview, Koska stated anecdotally that "a mother in India won't drink from the same cup, or drink from a cup and then pass it onto her baby, or vice versa. Everyone at the table or in the room, or on the floor will have their own cup because they literally won't do that lip to lip possible transmission, because of sanitation reasons". However, he stated, "when they go to a doctor, because the doctor is wearing a metaphorical white coat and a stethoscope, suddenly there is this false hope and false trust that surrounds the procedure, and they look away". He summarised with "I have asked 1000s and 1000s of schoolchildren in 60 countries: would they share a toothbrush with their neighbour? And they look horrified; they would go to the doctor and without a care or a thought, allow that doctor to put anything in their arm". The mission is to stop disease transmission through minimal product interventions. The main innovation of SafePoint is adopting a licencing model, requiring no upfront costs for a manufacturer; they incur the cost of the small modification to their existing equipment. Subsequently, SafePoint charge them a royalty, roughly one fifth of a US Cent, to a half of a US Cent, depending on certain factors, on each product.

\section{Figure 4: The Challenge.}

\section{Figure 5: The K1 Syringe.}

When questioned about how designers should respond in these social times; Koska stated, "there is no more or less value to a social enterprise compared to an enterprise. If, you know, someone is making syringes and they can make them at the right price and get them distributed well, then why would they not call that a business? Whereas, I am an inventor and I have licenced it out. It is exactly the same, just some people try and wrap it up with a different cover". Koska described that "we often miss out on the whole holistic chain that accompanies these products, and we lose sight of how many different faults that are outside our control. I was prepared to go into them and try and fix them a little bit, which hopefully, I have. It is not always easy... Your [designers'] area of excellence is probably something that you can control, but unfortunately, there are lots of other things that you have to control as well to pull it all together". 
The projects impacts include the uptake and training in numerous regions and international locations. For example, countless hospitals only use the K1 syringe. Among others, "SafePoint developed a relationship with Hindustan Medical Devices (HMD) in India, a family owned manufacturer, which can make quick changes as a supplier to a large area, developing business to business relationships". The business also invested heavily in the training of different medical practitioners, this should not be viewed as a "western power" flying in, but developing opportunities in collaboration over time.

The most important lessons are identifying details that can be manipulated in a holistic process. The solutions are embedded, they do not require extra training, just product redesign. The negative is that this process requires a vast resource, not just in finance but also time, contacts, gaining traction and addressing policy. The design work clarifies the problem, whilst understanding the deployment economics. The work had a deep research phase, co-created and developed over time for maximum impact.

\section{Case 3) On Our Radar}

A non-profit communications agency, On Our Radar focuses on under-reported stories from marginalised communities. In partnership with citizen journalists, one venture 'Back in touch' helped locals reflect on life in Sierra Leone after Ebola. Their process relies on community reporting differing from current citizen journalism models. They train networks trusted by local partners, with reporters nominated by their communities. Their training teaches how to: report safely, verify facts, deal with sources, finding stories, etc. Post submission reporter's stories and outputs are verified for accuracy. As the immediacy of the Ebola crisis dissipated, On Our Radar found its storytelling partners told more human stories about love, loss, work and life beyond fatalities. This yielded 'Back in touch', stories of people finding love and tackling loss after Ebola. Their method has produced broadcasts for Channel 4News, resulting in millions of viewers. The system has built associations between councils and remote villages, connected media with communities in crisis and provided community led insights. The founder, Libby Powell shared their design perspective.

A friendship with a dynamic photojournalist, who was tragically shot in Gaza and later passed, inspired founder Powell to go beyond pure journalism. An "opportunity came up to join Medical Aid for Palestinians. I spent five years, going between London and Lebanon, the Gaza Strip, the West Bank, talking with communities. Whilst there, the war in Gaza happened. The most powerful things we did were capture human stories, which remained untold. I entered a Guardian competition, on international development and ended up flying to Sierra Leone with a press pass to talk about disability. I was ferried around by NGOs, and community groups hearing positive stories of what young people with disabilities could do. I felt people with disabilities in Sierra Leone were being ignored, neglected, marginalised, and broke away to tell their stories. I produced a piece, full of anger at the way people are being treated, winning the competition, opening numerous doors. However, none of the journalistic work focused on human centric processes or feedback to communities. I endeavoured to bring the best practices in international development and community empowerment through journalism, a value driven journalistic practice, resulting in On Our Radar". 
On Our Radar's core mission is establishing an "inclusive society where everyone is heard on the matters that affect them most and can contribute to those solutions". One of their numerous impacts included a "young man called Seri Bangora, who was at our first training in Freetown, alongside photocopied training notes. He is a crutch user, so he came in early to make himself comfortable. He ended up being one of our most active reporters. He used a mobile phone; he'd never been online before. He was a proud young man but hadn't been heard much outside of the disability rights movement. He reported on a massive democratic moment for his country using text messages, as his only means of communicating with us. As a result, he ended up working for us as a paid trainer".

The "Ebola outbreak hit, and the team was right in the middle of Freetown amongst all of the health crisis. They sent quotes by text message and recorded voicemails. They painted this incredible picture of the Ebola outbreak as it was happening, but well beyond the spaces where the cameras could reach, behind the quarantine lines. After the Ebola outbreak, he helped to provide stories for the BBC and for Aljazeera, and for Channel 4. After the Ebola outbreak dissipated he then trained a group of girls who were unable to return to education, helping them to tell their story about the Ebola outbreak. He's now established an organisation using ISMS technology to help young people with disabilities report to the police".

Powell stated, "If you are creative, you think fast, it's really easy to come up with incredible creative solutions using technology or social design to solve issues. Unless you have direct experience of that issue, you rarely fully understand the problem behind it. Due to projects that have almost failed, the only true way to design solutions is to understand the problem, through the eyes of those most affected. That doesn't mean tokenism; it means the solution request comes from them, or a welltimed piece of scoping work, enabling the users to lead the design. I suggest that people undertake a role as facilitators, more than tech practitioners or innovators".

\section{Case 4) Public Laboratory of Open Science (PLOTS)}

British Petroleum's, “Deepwater Horizon erupted oil into the Gulf of Mexico, causing catastrophic effects on over 15,000 species from orcas to endangered crocodiles" (Meigs, 2016). It cost lives and shattered the livelihoods of hundreds of thousands of; fishermen, oil workers, hotel staff and more, heavily dependant on the coastline. The "company convinced authorities to restrict spill areas as a no-fly zone, making it impossible to witness impacts" (Vaughan, 2018). The 'Grassroots Mapping' group collaborated with environmental activists to fly balloons holding cameras over the spill, mapping the devastation. The group used 'flying cameras' to collect in excess of ten thousand aerial photographs of irreparable damage. Images were stitched together with open source software, forming up-to-date maps; more detailed than satellite imagery. Media channels including "The New York Times and CNN published the findings with Google Earth publically posting maps" (https://publiclab.org/).

The activists formed 'The Public Laboratory of Open Source Science', PLOTS or 'Public Lab' (a non-profit). They are a community, developing and applying opensource tools for environmental exploration and investigation: consisting of "activists, educators, technologists, and community organizers interested in new ways of promoting action, intervention, and awareness through participatory research" 
(https://publiclab.org/). They design with inexpensive equipment and accessible with 'Do-It-Yourself' techniques. Their community experiments widen participation; relying on people's passion for data, they're environment and their investigation locality (https://publiclab.org/). Their manifesto encapsulates the movement's approach that 'products' must be low cost, have data legibility, ease of use, public participation, creative reuse of consumer tech, open source and user modifiable. They involve people and communities without formal training, restructuring the citizen science model, as anyone can contribute. This leverages participant's motivation to explore their surroundings, based on their geographic interests. Jeff Warren, research director for PLOTS, shares their approach.

Figure 6: Using the PLOTS Kit.

\section{Figure 7: Aerial Shot from Kit.}

The Public "Lab was a community before we were an organisation. The seven founders of Public Lab met, during the BP oil disaster". The mapping "kit means lots of things to lots of people. It was a huge disaster; BP and the Coastguard heavily controlled it. It was very serious, but also an energising way engage and do things they didn't think we could". Those "values are embodied in the mapping kit and process. We strongly believe that the objects people create together carry a bit of their essence and ideas. There was something about all the little decisions about that kit, how it was taught and learnt, how we had events around it, how people thought and spoke about it. That's one reason that it has gone on to live in other places sharing that kind of attitude".

For Public Lab, "we think it's really important not to think that technology is just a transformative thing, that's going to change everyone's lives for the better. It's not that technology is the centre. It's the perspective, the people, who are at the centre. How people are able to use technologies tactically and culturally, and make cultural projects that transform relationships and make them more equitable. Part "of the balloon mapping story is that people are collecting information more like a photographer than a scientist. They're choosing the photo. The traditional model of data collection is that science is all-seeing or it systematically collects. Balloon mapping really changes that, because you're really going out and capturing shots, exposing something happening. That's more like a reporter than someone processing data, and a sharp contrast with citizen science. People extend the 'machine' way of thinking about data collection".

The "important lesson I've learnt is our work is cultural. People think we're making things, creating technologies, or doing science. We're bringing people together, negotiating collaboration, where all parties' gain... levelling the playing field... the hardest work is cultural work. Getting people to see their viewpoint is not the fundamental viewpoint, but acknowledge the wider story. People's whole lives have often been in a particular cultural frame, and that's difficult to escape". The "fundamental part of Public Lab, is helping people see a little beyond that and acknowledge one another's frames. That's cultural work, and it's harder than technological challenges". Choosing and "defining the problem, is the first step. Framing problems, framing questions, that's one of the most important moments, and it's one that is skipped over in a lot of different workflows or models. Collaborative models really need exploring... The more we think about it, the more we think of 
ways to re-engage with collaborative working to define a problem. One difference of Public Lab is the interplay between objects and hands-on processes, on conceptual, political and social ideas. Objects can; enable discussions, provide catalysts, or open spaces, to different kinds of making, which change these relationships.

\section{Case 5) Field Ready}

A non-profit Field Ready is a humanitarian organisation, filling a methodology gap in the delivery of international aid. Their vision is guided by transforming how needs are met and assets/capabilities are created and built. Their concept meets humanitarian need by transforming logistics through technology, innovative design and participation. Field Ready brings manufacturing to challenging places, training others to locally solve problems e.g. health, water and sanitation. They scale their approach to the scenario dramatically improving efficiency in aid delivery, meeting needs to reduce; costs, transport and time. They use technology i.e. 3D printers, laser cutters and traditional manufacturing to share skills through training within tough challenges. Their approach embraces; mutual respect for others, openness to learning, experimentation and engaging wide-ranging stakeholders.

Their principles include: 1) Professionalism, operate in a financially sustainable manner oriented toward effective programs, positive change and learning. 2) Appropriateness, effectively develop products and services that are practical for people in need including those working in response. 3) Partnership, The enormous challenges faced in humanitarian contexts require unification. They work in close cooperation with others sharing mutual goals. 4) Adherence to humanitarian principles including humanity, independence and impartiality. Field ready's mission is international aid development through access to goods "where they need them and when they need them" (www.fieldready.org/). They achieve international impact through; online free and open sharing of reliable designs for essential humanitarian supplies, a strong community of expert designers and engineers to support local people with custom design assistance, robust manufacturing equipment suitable for field use that is repairable and maintainable. During Interview Eric James, founder, shared his inspirational insights.

Figure 8: Production of Inflatable Units.

\section{Figure 9: Testing The Inflatable Units.}

James stated "Humanitarian supply chains account for a huge portion of development assistance that goes overseas. Up to $60-70 \%$ of humanitarian aid is devoted to logistics. If we can reduce that, we're talking about a major cost saving, making things far cheaper than they currently are; we're talking about doing it far faster, because if we're making things where they're needed it can be done, in some cases, in just a number of hours. Because we're able to pass on skills to people locally they can do repairs and reach mass production without relying on long processes". Their impactful examples have included "babies in Haiti missing umbilical cord clamps, forced [due to resource access] to use things like discarded shoelaces, that can be contaminated, leading to sepsis; resulting in increased child mortality".

In the "worst humanitarian crisis we've faced since the Second World War, the Syrian Civil War. We know about bombs being dropped on cities, collapsed buildings, and people rescued from rubble. Rescue teams were underequipped, and, rescue 
equipment can be very expensive, a good way to lift slabs of concrete didn't exist. Usually you only need to lift them a few inches, sometimes, to be able to pull people out. There is equipment that does that costing up to $\$ 5,000$ ". Field ready found a "British standard for, 'rescue airbag's - and created a process to make them at a tenth of the cost in Syria. The project was first used to rescue a mother and daughter and now being distributed to rescue teams in Syria".

James commented "you have to start with a clear identification of what problems, singular or plural - that you're going to work on, and that requires refinement and its communication. A second insight is bringing in or making a strong team. We're not all aid workers, we're not all engineers, because, you know, that would've led to a certain thing. We have a designer, a large set of diverse engineers, people with different experiences. We're aid workers with management and commercial start-up experience etc".

Finally, "design and create processes to get out of the building. In the 20 plus years I've been working, the idea 20 years ago that all refugees would be talking to themselves on mobile phones that were connected to the Internet. You have to get outside of the box and think about things like post-normal times. This is what we're doing with Field Ready, it's about what we can do in the future with it and how we can shape that for a social good that's so important".

\section{Case 6) The Bevy}

Pubs are central to communities as they; level people socially, build community support and companionship. Historically "Moulsecoombe near Brighton has been plagued by crime and unemployment" (Verisure, 2018). The Bevy seeks to buck that history, providing community run amenities. Anyone can become a shareholder for $£ 10$, and they are winning 'Best Business in the Community' awards in Brighton. They own a wheelchair accessible 'Bevy Bus' to collect residents for community clubs, bringing their sponsored rugby team back after games and takes local Albion football fans to every home game. The initiative helps young people bridge a burgeoning challenge of work experience, a prerequisite for modern employment. They host plant sales, provide fruit and veg to their lunch club and make puddings, jams and pickles raising funds for their community Christmas events.

They have partnered with local St. John's College, bringing students to work in the kitchen delivering meals and building skills. The pub works with the local council's learning disability employment team offering short work placements behind the bar. Volunteers; mow lawns, fix the drains, collect glasses (when busy), do a bar stint, organise events and tackle business paperwork. The Bevy runs "budgeting workshops; hosted health checks and monthly councillor drop in surgeries and sponsor a student rugby team who in exchange do some volunteering" (Anonymous, 2018a). They are working with local breweries to launch their own beer, leading to more employment and sustained revenue. Cofounder Warren Carter, shared their approach.

The pub "closed by authorities, remained shut for years. Locals felt Moulsecoombe and Bevendean Estates were isolated as the location was in the countries bottom 5\% for deprivation. We looked at community pubs, realising we were the UK's first 'housing estate pub'. We knew, if we reopened to keep it commercially viable, we 
had to be more than a pub". Pubs "are, in our DNA, if run properly, they include anyone". The Bevy "needed to be like your front room, with activities and a place to meet. An old-fashioned pub where people knew everyone, with good service, was affordable, but the mission was always a back to front community centre, with countless activities to benefit the neighbourhood".

The Bevy had, "a bad reputation and was seen as an unviable pub. The first email I got was from a local copper saying, 'There's no chance we're going to let you reopen this pub,' leading to perception issues. We were in a unique position so it's been a struggle financially. We don't own the building, so we're not getting rent from flats upstairs, so it's standalone, in an area with lots of poverty. Their ethos reflects the fact "it's a pub, a community centre and we want to be there for everyone within the neighbourhood. Since forming, we run clubs, choirs, Friday Friends disability groups, cooking in the kitchen, a training kitchen for children, pigeon clubs and normal things you'd find in a pub. If someone comes up with an idea, we try and make it happen, it's good for The Bevy, good for the business and it really gets people engaged".

One of their strongest impacts is their Friday Friends Seniors' club, "helping up to 40 older residents a week. They get picked up by minibus have lunch, a laugh and a bit of bingo. It tackles loneliness head on giving people the chance to get out of their four walls, encouraging conversation and community. Some of our work with disabled people has been amazingly impactful. It's still a working-class pub, with numerous builders finishing work and have a drink. St John's College for young adults with learning disabilities run a kitchen two or three times a week and we offer work experience behind the bar. We want to build opportunities for people with disabilities, who are never given chances to work. We can't afford chefs, because we don't make enough money from the food. So, we married the two, the work experience, so people can get a stepping stone to proper jobs and paid work".

The "pub wouldn't survive without volunteers, if you walked into Wetherspoons and they said, 'oh, we're busy, can you clear the glasses?' or, 'we've run out of loo roll, can you pop to the shops?' you'd tell them where to go". They "want to be everyone's pub, whilst making savings because, commercially, we're an unviable pub, socially we're massively viable". The "trick for funders and charitable foundations is supporting people in true need that struggle with paperwork. We want to be a blueprint for pubs in the future, it's hard work, you must be bloody-minded and people need to visit parallel projects learning from them".

\section{Collective insights}

In Community Technology, Hess states "without community, technology cannot function and vice versa" (Hess, 1979), 70\% of all interviewed organisations stated that building a network or community was the most important endeavour to establish socially led design. $65 \%$ of participants commented that it was not only important to prototype early, but engage audiences in live feedback of prototyping as early as possible. The following were reoccurring themes throughout all of the interviews conducted:

- Non-colonialist perspectives are critical to ensure accuracy to be culturally and ethically independent. Insights are not always transferable from one culture or situation to the next. 
- Engage Appropriate Organisations. The need to build teams, enabling appropriate responses. This is dependant on the 'gatekeepers' to those communities ensuring ethics are closely adhered to.

- Minimal viable product option, what is the cheapest and what the most appropriate solution are, do not always go together, they are about context (Ries, 2018). Trialling the least abstract and tangible concept that people, investors can understand.

- Collaboration, this is fundamental as it always requires a number of collaborators

- Appropriate intervention(s). Field Ready is a shining example as they use accessible tools appropriate to their audience. They "Access, Design, Make, Share, Lead" as their process (Anonymous, 2018b). Public lab support appropriateness through their design guides as all material has to be "low cost, open source, easy to use, built through public participation and collaboration, supported by a network of practitioners and produce meaningful, understandable high quality data" (Anonymous, 2012).

- Location and Provenance, Solid Wool celebrate this as they are rebuilding an economy with local resources.

- Accessibility to enablers, On our Radar, designed itself based on the resources that people had access to, enabling the widest audience possible.

\section{Discussion}

The interviews raised a number of repeatable insights but still face a number of challenges in Intellectual property, finance, accessibility and motivation. Design society (by the community), Designing for (local variables and deployment), Design for agency including lead and lay audiences (civic empowerment), Designing (for human rights), Design licensing (better for user, producer and business).

\section{Intellectual Property}

Ownership when it created by a community, this will hopefully become easier in the future, but currently outside of creative commons or social innovations it is hard for businesses to upscale that could have tradable Intellectual Property. This could lead to a silo-ing of approaches as operations should be more cross-disciplinary with economic models, not just design models.

\section{Sustainable financial models}

The "most effective methods for cultivating social innovation start from the presumption that people are competent interpreters of their own lives and competent solvers of their own problems" (Mulgan, 2006). The Library of Things for example "is a treasure box of useful and joyful Things in your local library, housing block, cafe or workspace. There, you can: Borrow Things like drills, strimmers \& Go Pros by the day or week, Join practical events like DIY classes \& Mending Meet-ups or Volunteer \& get to know your neighbours: organise events, fix Things" (Trevalyan, 2018). This initiative is now aligning with large manufacturers as part of an Research and Development department to understand wear, seeing a benefit in socially led thinking. The challenges still remain in how Social innovations scale as they reach capacity and require resources, wages and infrastructure that goes beyond donations. Governments "have often played the critical role in scaling up social innovations. They have unique capacities to do this by passing laws; allocating public expenditure" (Mulgan, 2006). 


\section{Decolonizing}

Design "is regarded in the article as an ontological instrument that is able to transform the social and cultural reality, and model human experience, subjectivity and environment" (Tlostanova, 2017). Tlostanova highlights the issues of 'Decolonizing Design' as all of the concepts and insights presented here are contextually based and will not always translate. Decolonizing design, is not a question of "improving the status quo but a question of learning to differentiate between designs that facilitate the productivist drive towards devaluing and appropriating human and non-human natures, and designs that facilitate a process of delinking and redirection into other modes of being/becoming" (Tlostanova, 2017).

There "is currently not enough critical reflection on this in the interrogation of coloniality in design, nor is there enough self-reflection on the techno-mediating methods through which "decolonizing" design is explored" (Tlostanova, 2017). Designing for The Common Good reinforces that "Design can be evil [and it] is important to 'do no harm' and anchor back to an acute understanding of the 'common good" (Dorst, Kaldor et al. 2016). Whilst it is easy to polarise any argument, designers and wider communities need to review what ethical values are to them and how they are embodied. Designing for agency is an interesting social construct provided by the interviewee-ed, it sits along side the ethical solutions that we need to design for.

\section{Accessibility}

In Designing for The Common Good, (Dorst et al. 2016) emphasises the importance that "identity and openness [are important] values that can only be achieved if the community participates in a hands-on way". There is a common myth that, accessible means non-financial, it does not have to be free, but 'access' can be many different things. Citizen Designer, Perspectives on Design Responsibility (Heller, Vienne 2003) highlights "designers must be good citizens and participate in the shaping of our government and society" we should also provide people with. Recent Citizen Sensing project believes that "empowerment, openess, co-creating ang changemaking" are key to the next steps of the design industry (Making Sense, 2018).

\section{Motivation to engage/respond}

Motivation is a huge factor and relied on communities for positive engagement, if interventions are not solving individuals 'challenges', then motivation is required. This builds on the more practical side of things raised by a recent report Understanding Motivations for Citizen Science that the "overwhelming reason preventing respondents for doing more volunteering was 'lack of time" (Geoghegan, Dyke et al. 2016). These opportunities if reliant on individuals in the volunteering sector need to provide other means, not just for social good. Social innovations "are often implemented early, because those involved are usually highly motivated, they are too impatient to wait for governments or big foundations" (Mulgan, 2006).

\section{Conclusion}

The organisations highlighted are going beyond 'participatory' and using different methods to 'engage design' to identify issues and create sustainable finance. On our Radar created 'training for the trainers', PLOTS, created agency, SimPrints is designing for human rights and Field Ready were specifically designing for contextual deployment. The K1 Syringe designs for 'good business', that is 
financially sustainable, exportable with high standing accreditation, giving manufacturers added value. The Bevy is aiming to reduce barriers to entry helping disabled young people obtain work experience, whilst providing a valuable resource for the community. Motivation will always remain a barrier as Geoghegan Raises the following challenges for participation in socially led Citizen Science activities "Motivation, Funding, Personal circumstances, Enthusiasm, Networking/social factors and Length of time" (Geoghegan et al. 2016). PLOTS have a "better for the individual better for the masses', working to engage with others an architecture and output that we all aspire to. The opportunities highlighted through the interviews are when the alignment of social benefit, business benefit and the end users it provides motivation in its own right.

\section{Future work}

Comprehend how the organisations different approaches would work in different cultures, contexts and locations, as they are not a 'silver bullet', but understanding barriers would be invaluable. Trial by practice 'engaging design' to test more diverse scenarios of how these approaches would work. Analysing a more unified design and business approach to challenges, to highlight what is truly financially sustainable over time yielding to collaborative and positive, mutual benefits for all.

Appendix Notes: SIZE OF FIRMs, when established

\begin{tabular}{|c|c|c|c|c|c|c|}
\hline $\begin{array}{l}\text { Civic } \\
\text { Empowerment }\end{array}$ & Healthcare & $\begin{array}{l}\text { Environment \& } \\
\text { Sustainability }\end{array}$ & $\begin{array}{l}\text { Accessible } \\
\text { Design }\end{array}$ & $\begin{array}{l}\text { Economic } \\
\text { Empowerment }\end{array}$ & $\begin{array}{l}\text { Community } \\
\text { Engagement }\end{array}$ & $\begin{array}{l}\text { Access to } \\
\text { Knowledge }\end{array}$ \\
\hline Better Shelter & Cola Life & Farm bot & Sugru & PET Lamp & $\begin{array}{l}\text { Casserole } \\
\text { Club }\end{array}$ & Open Utility \\
\hline Fix my Street & Safe Point & Fairphone & Wiki House & $\begin{array}{l}\text { Motivation } \\
\text { Wheelchairs }\end{array}$ & Fixperts & $\begin{array}{l}\text { Wonder } \\
\text { connection }\end{array}$ \\
\hline $\begin{array}{l}\text { Future Sense } \\
\text { Project }\end{array}$ & $\begin{array}{l}\text { Response } \\
\text { Monitor }\end{array}$ & Shower Loop & Nature Bytes & PlayPump & $\begin{array}{l}\text { New Old } \\
\text { Exchange }\end{array}$ & Bento Lab \\
\hline Solar Stove & $\begin{array}{l}\text { Mamaope } \\
\text { Jacket }\end{array}$ & Gravity Light & Open Structures & Hiut Denim & $\begin{array}{l}\text { The Bevy, } \\
\text { Social Pub }\end{array}$ & Restart project \\
\hline Open Toilets & Faircap & $\begin{array}{l}\text { Smart Hydro } \\
\text { power }\end{array}$ & Kniterate & Azuko & $\begin{array}{l}\text { New ground } \\
\text { cohousing }\end{array}$ & $\begin{array}{l}\text { Elephant } \\
\text { Listening } \\
\text { Project }\end{array}$ \\
\hline Litterati & Ode & KTK - belt & Ambionics & Open Desk & Solidwool & Foldscope \\
\hline Public lab (PLOTS) & Diva Centres & Land life & Field Ready & Sim prints & $\begin{array}{l}\text { Library of } \\
\text { Things }\end{array}$ & Smart Citizen \\
\hline Peoples Fridge & $\begin{array}{l}\text { Drinkable } \\
\text { Book }\end{array}$ & Farm Hack & Safecast & & & \\
\hline \multirow[t]{3}{*}{ On Our Radar } & Make Health & Solar lamp & Precious Plastic & & & \\
\hline & $\begin{array}{l}\text { Virtual } \\
\text { doctors }\end{array}$ & $\begin{array}{l}\text { Wave powered } \\
\text { energy }\end{array}$ & $\begin{array}{l}\text { Open Water } \\
\text { project }\end{array}$ & & & \\
\hline & & Plastic Tide & & & & \\
\hline
\end{tabular}

Table 2: Organisational information.

\section{Acknowledgements}

We would like to thank the Royal College of Art Design Products department for assisting in gathering the community and outreach enabling this work. We also thank the following participating projects; Safecast, Cola life, Safe Point, Farm bot, Fairphone, Sugru, PET Lamp, Motivation wheelchairs, Wiki Houses, Play Pump, Open Utility, Hiut Denim, Smart Citizen, Better Shelter, Casserole club, First 
Response Monitor, Mamaope anti-pnumonia jacket, Fix my street, Future sense project, Fixperts, Faircap, Solar Stove, Shower loop, gravity light, Naturebytes, Ode, Tech for Trade, Diva Centre, Open Toilets, Smart Hydro power, Safe Water Book, Wonder connection, Foldscope, Vertical University, Open Structures, Litterati, Solid Wool, Make Health, Land life, New Old Exchange, 10\$ wind turbine, Public Laboratory of Science and Technology, Farm Hack, Bio-lite, Solar lamp, Wave powered energy, Simprints, Virtual doctors, Kniterate, Bento Lab, Peoples Fridge, Restart project, New ground cohousing, Plastic Tide, Open Desk, The Bevy Social Pub, Elephant Listening Project, Kids prosthetics, Big data water, Precious Plastic, Azuko, Open Water project, Library of Things, Field Ready and On Our Radar.

\section{References}

ANONYMOUS, (2018), 'The Bevy, more than a pub', http://www.thebevy.co.uk/. Accessed August, 10th, 2018.

ANONYMOUS, (2018), 'Field Ready - Our Approach', https://www.fieldready.org/approach. Accessed, August, 1st, 2018.

ANONYMOUS, (2018), 'The Safepoint Trust', https://www.safepointtrust.org. Accessed August, 2nd, 2018.

ANONYMOUS, (2012), 'The Public Laboratory for Open Technology and Science', http://publiclaboratory.org/home, Accessed November, 01, 2018.

BRABIN, B.J. (2014), 'Malaria's contribution to World War One-the unexpected adversary'. Malaria journal, 13: 1, pp. 497.

BRIDGES, M., KUO, K., SINGH, M., WALTERJ. (2018), 'The 2018 annual meeting report of the World Economic Forum', Geneva: World Economic Forum.

BROWN, T \& WYATT J, (2010), 'Design Thinking for Social Innovation', https://ssir.org/articles/entry/design_thinking_for_social_innovation. Accessed 10th, August 2018.

CAHALAN, A. (2007). The Future of Design. Education, AGDA.

CHEN, D., CHENG, L., HUMMELS, C. and KOSKINEN, I. (2016). 'Social design: An introduction', International Journal of Design, 10:1, pp. 1-5.

CLARK, L. (2015), 'Why it took 15 years for a smarter, safer syringe to be accepted' https://www.wired.co.uk/article/marc-koska-lifesaver-k1-syringe-wired-health-2015. Accessed August, 10th, 2018.

COOPER, R. (2005), 'Ethics and altruism: what constitutes socially responsible design?' Design Management Review, 16:3, pp. 10-18.

DAHMUS, J.B., GONZALEZ-ZUGASTI, J.P. and OTTO, K.N. (2001), 'Modular product architecture', Design Studies, 22:5, pp. 409-424.

DENIZEN, S. (2018), Landscape and Agency: Critical Essays.

DEPARTMENT OF PROTECTION OF THE HUMAN ENVIRONMENT, DEPARTMENT

OF VACCINES AND BIOLOGICALS. (2002), '"First, do no harm" Introducing auto-

disable syringes and ensuring injection safety in immunization systems of developing

countries', WHO/V\&B/02.26, Geneva: World Health Organisation.

DESIGN COUNCIL, (2017), 'Designing a Future Economy, Developing design skills for productivity and innovation', London: The Design Council.

DESIGNKMG, (2018), 'Technology Push \& Market Pull',

http://designkmg.weebly.com/technology-push--market-pull.html. Accessed August, 10th, 2018.

DICTIONARY, O.E. (2006), Concise Oxford English Dictionary, 6 edn. Oxford: Oxford University Press. 
DORST, C.H., KALDOR, L., KLIPPAN, L. and WATSON, R. (2016), Designing for the common good. 1 edn. Building Het Sieraad Postjesweg 11057 DT Amsterdam The Netherlands: BIS publishers.

EMMERSON, J, (2018), 'Design Matters', https://frieze.com/article/design-matters. Accessed August, 10th, 2018.

EPPINGER, S.D. and ULRICH, K.T. (1995), Product design and development. 1 edn. McGraw-Hill New York.

FIXSON, S.K. (2005), 'Product architecture assessment: a tool to link product, process, and supply chain design decisions', Journal of Operations Management, 23:3-4, pp. 345-369. GALL, M.D., BORG, W.R. and GALL, J.P. (1996), Educational research: An introduction. 7th edn. Boston: Longman Publishing.

GEOGHEGAN, H., DYKE, A., PATEMAN, R., WEST, S. and EVERETT, G. (2016), 'Understanding motivations for citizen science'. Natural Environment Research Council, Polaris House, North Star Avenue Swindon, Wiltshire, SN2 1EU: Environmental Observation Framework.

HESS, K. (1979), Community technology. New York ; London: Harper and Row. IDEO, (2015), The Little Book of Design Ethics, 1 edn. London: IDEO.

IRWIN, T. (2015), 'Transition design: A proposal for a new area of design practice, study, and research', Design and Culture, 7:2, pp. 229-246.

JACOBS, M.A. and SWINK, M. (2011), 'Product portfolio architectural complexity and operational performance: Incorporating the roles of learning and fixed assets'. Journal of Operations Management, 29:7-8, pp. 677-691.

MAKING SENSE, (2018), Citizen Sensing, A Toolkit. Barcelona: Making Sense.

MANDELBAUM-SCHMID, J, (2015), 'WHO calls for worldwide use of "smart" syringes', http://www.who.int/mediacentre/news/releases/2015/injection-safety/en/. Accessed August, 10th, 2018.

MANZINI, E. and COAD, R. (2015), 'Design, When Everybody Designs: An Introduction to Design for Social Innovation', MIT Press.

MEIGS, J.B, (2016) 'Blame BP for Deepwater Horizon. But Direct Your Outrage to the Actual Mistake', http://www.slate.com/articles/health_and_science/science/2016/09/bp_is_to_blame_for_deep water_horizon_but_its_mistake_was_actually_years.html?via=gdpr-consent. Accessed August, 10th, 2018.

MULGAN, G. (2006), 'The process of social innovation', Innovations: technology, governance, globalization, 1:2, pp. 145-162.

PANDA, B. (2007), 'Top down or bottom up? A study of grassroots NGOs' approach', Journal of Health Management, 9:2, pp. 257-273.

PAPANEK, V. and FULLER, R.B. (1972), Design for the real world. 2 edn. London: Thames and Hudson London.

RATTO, M. and BOLER, M. (2014), DIY citizenship: Critical making and social media. MIT Press.

RIES, E, (2018), 'The Lean Startup Methodology', http://theleanstartup.com/principles. Accessed August, 10th, 2018.

RITCHIE, J., LEWIS, J., NICHOLLS, C.M. and ORMSTON, R. (2013), 'Qualitative research practice: A guide for social science students and researchers'. 1 edn. London: sage. SOSA, M.E., EPPINGER, S.D. and ROWLES, C.M. (2004), 'The misalignment of product architecture and organizational structure in complex product development', Management science, 50:12, pp. 1674-1689.

STONE, R.B., WOOD, K.L. and CRAWFORD, R.H. (1999), 'Product architecture development with quantitative functional models', Proceedings of the Design Engineering Technical Conferences. 
THE DESIGN COUNCIL, (2013), 'The "double diamond" design process model', http://www.designcouncil.org.uk/designprocess. Accessed February, 8th, 2013.

THE NOMINET TRUST, (2018), TRANSFORMING LIVES WITH TECH: A GLOBAL CONVERSATION. London: The Nominet Trust.

THE WORLD BANK, (2018), IDA17 Maximising Development Impact, Leveraging IDA to meet global ambitions and evolving client needs. Washington: International Bank for Reconstructions and Development and International Development Association / The World Bank.

THORPE, A. and GAMMAN, L. (2011), 'Design with society: why socially responsive design is good enough', CoDesign, 7:3-4, pp. 217-230.

TLOSTANOVA, M. (2017), 'On decolonizing design', Design Philosophy Papers, 15:1, pp. 51-61.

TREVALYAN, R, (2018) 'The Library of Things', https://www.libraryofthings.co.uk/home/\#howitworks. Accessed February, 24, 2018.

VAN DER ZWAAG, A. (2014), Looks Good Feels Good is Good - How Social Design Changes Our World. 1 edn. Amsterdam: van Zoetendaal.

VAUGHAN, A, (2018) 'BP's Deepwater Horizon bill tops \$65bn, Firm's financial pain offset by rising oil prices as it winds down payouts from 2010 disaster',

https://www.theguardian.com/business/2018/jan/16/bps-deepwater-horizon-bill-tops-65bn.

Accessed August, 10th, 2018.

VERISURE, (2018), 'Brighton Crime statistics', https://www.verisure.co.uk/advice-andhelp/crime-statistics/brighton-crime-statistics. Accessed October 10th, 2018.

WADE, N. (1975), Karl Hess: Technology with a human face.

WILLIAMS, Z, (2018), 'The People's Supermarket: where even the smell of baking bread is genuine', https://www.theguardian.com/theguardian/2012/mar/02/london-peoplessupermarket-cooperatives. Accessed August 10th, 2018, 2018.

WORLD ECONOMIC FORUM, (2018), Global Risks Report 13th Edition. Geneva: World Economic Forum.

YU, J.S., GONZALEZ-ZUGASTI, J.P. and OTTO, K.N. (1999), Product architecture definition based upon customer demands', Journal of Mechanical Design, 121:3, pp. 329-335.

ZAMIROWSKI, E.J. and OTTO, K.N. (1999), 'Identifying product family architecture modularity using function and variety heuristics', 11th International Conference on Design Theory and Methodology, ASME, Las Vegas. 